\title{
Perspectives and Obstacles for Afghanistan to be a Part of the China's Belt and Road Initiative
}

\author{
Anita Dkhar ${ }^{1, *}$ Mohammad Alem Mohammad Tamim ${ }^{1,2, a}$ Saydi Sayed Walid ${ }^{1,3, b}$ \\ ${ }^{1}$ Department of theory and history of international relations, RUDN University, Moscow, Russia \\ ${ }^{2}$ Khair Khana, Kabul, Afghanistan \\ ${ }^{3}$ Macrorayan, Kabul, Afghanistan \\ ${ }^{a}$ Email: tamim.hashemi0043@gmail.com \\ ${ }^{b}$ Email: Saidy.walid@mail.ru \\ *Corresponding author.Email: ann_dhar@mail.ru
}

\begin{abstract}
The article is devoted to the problem of Afghanistan's association to the China's Belt and Road economic initiative that has been widely and actively spreading across the world and Eurasia in particular since 2013. Authors analyze the opportunities for Afghanistan to join the China's global economic initiative, consider factors positively and negatively influencing the given perspectives and reveal features of regional development and bilateral relations between Afghanistan and China as key factors influencing the actions of the Afghanistan's diplomacy on the way to the cooperation within the global initiative. In conclusion, authors provide key observations of the research based on the opportunities and challenges of Afghanistan within the regional connectivity.
\end{abstract}

Keywords: Afghanistan, China, Bilateral relations, Belt and Road strategy, Security, Infrastructure, Regional connectivity.

\section{INTRODUCTION}

Trade has held a key role within the economic, political, cultural and other spheres of cooperation among the nations since ancient times, implying one of the drivers of the state development. One of the greatest trade routes that provided the opportunities for comprehensive cooperation resulting in the rapid economic growth was the Great Silk Road connecting China, India and South-East Asian countries with Europe. Whereas, Afghanistan possessed the most advantageous geopolitical and geostrategic position within the route, being exactly located on its transit lines. It was here, through the Wakhan corridor - a narrow, 15 kilometers wide, neck between the mountains in Badakhshan - that the first Great Silk Road passed.

In the modern times, in 2013, China officially announced its goal to set up the global initiative to restore the ancient route within the Belt and Road economic project (BRI) connecting 70 countries and organizations of the world. The BRI provides the establishment of multiple projects along its economic land belt and maritime road, designed to connect China with some of its most important markets across Europe, Asia and beyond.

Afghanistan's unique geographical position makes it an important link between South and Central Asia, as well as East and West Asia. It is also rich with natural resources that could pave the way for economic growth. However, the country has not been able to leverage these advantages to facilitate economic development due to a long history of war and political instability.

China is increasingly pushing for Afghanistan to take up a position as a central player in Central and South Asia. Initially, due to its conflict-ridden condition, Afghanistan had been excluded from China's Belt and Road Initiative. However, more recently China has developed greater interest and became more inclined to include Afghanistan due to its pivotal role in connecting Chinese markets to the rest of Asia, Europe and East Africa.

The article is devoted to the problem of Afghanistan's participation in the BRI initiative. The 
main goal of the article is to reveal the motives of Afghanistan to be a part of the global initiative, its prospects and obstacles taking into account the regional security issues.

The Afghanistan development issues have been studied by both Russian and foreign scholars. The Russian group might be represented by the researches of V. Y. Belokrenitsky, M.A. Dyakonova, F.F. Sharipova, D.B. Malysheva. The authors objectively analyze the given issue, touching upon historical facts and geopolitical conditions of the country and the region that makes it possible to examine and consider the actors' actions of that period and make certain conclusions.

The south Asian researches are also represented by works of Ahmad Bilal Khalil, lead researcher of the Center for Strategic and Regional Studies in Kabul who specializes in regional geopolitical and geo-economic matters, as well as Afghanistan's relations with its neighbors (especially China, Pakistan, and India), that provides analysis on the perspective for Afghanistan in joining the ChinaPakistan economic corridor as a tool for stabilization for the Afghan-Pakistan bilateral relations and issues of regional security. Another prominent Afghan researcher is Mariam Safi, Founder and Executive Director of the Organization for Policy Research and Development Studies in Afghanistan, who provides a detailed analysis of the Chinese steps towards facilitating relations with Afghanistan within the BRI initiative and related obstacles.

\section{CHINA - AFGHANISTAN RELATIONS: THE BRI PERSPECTIVES}

In 1960 China and Afghanistan signed the bilateral Friendship and Mutual Non-Aggression Treaty [1]. In 2006, both countries reaffirmed their 1960 Treaty founded on principles of «good neighborly» relations stating the China's strong support to Afghanistan and its neighbors' stabilization process.

The relations of China and Afghanistan also proceed from their neighborhood implying the 92,45 $\mathrm{km}$ common border. The given space is of high importance for Chinese policy with regard to the Uighur separatist groups located in Xinjiang Uyghur Autonomous Region that allegedly possess connections with rebel groups in Afghanistan [2].

In addition, Afghanistan has a serious infrastructure deficit that ideally complies with the opportunities provided by Chinese investments, since the country possesses the shortest route between Central Asia and South Asia, as well as between China and the Middle East, which also serves as a gateway to the Arabian Sea.

Moreover, the U.S.-led military drawdown in 2014 had created the potential for a security vacuum to fulfill, which China used and increased its presence in Afghanistan by stating the afghan direction as a priority on its western borders [3].

Today China is the largest business investor in Afghanistan, even under the conditions of the military-political occupation by the United States. Already in 2007, a Chinese corporation won copper mining rights of nearly 3 billion USD worth in Afghanistan's Ainak field that had not been developed in the course of armed conflict.

In 2011, Afghanistan signed a 25-year contract with China's state-owned oil corporation CNPC covering the drilling and prospective construction of refining facilities in the northern provinces of Faryab and Sari Pul, which became the first commercial oil production in the country.

Even the primary steps to include and integrate Afghanistan into the BRI have also already been taken. Afghanistan and China signed a Memorandum of Understanding on the BRI in 2016. China's deputy ambassador $\mathrm{Wu}$ Haitao emphasized that «the Belt and Road initiative is conducive to Afghanistan's reconstruction and economic development as well as the integration of Afghanistan into regional development» [4], which indeed positively affected the country's further development.

The air corridor connecting Kabul and the Chinese city of Urumqi was the first project to be launched under the official label of the Belt and Road initiative, although no official negotiations on Afghanistan to join the project held by that moment [5]. Later on, the first railway connecting the two countries built in Afghanistan within the BRI had passed the first direct cargo train from the Jiangsu Province (China) to the Afghan border town of Hairatan.

Furthermore, in 2017 following the visit of Afghani officials to China within the Belt and Road Forum, Afghanistan officially joined the Asian infrastructure and investment bank that finances the projects of the Economic initiative. China also supports the membership of Afghanistan in Shanghai cooperation organization and the counter-terrorism association of member countries. 
Finally, The Digital Silk Road implemented by ZTE and Huawei may enable Afghanistan to become a major trade and transit hub for subsea and transcontinental communication possessing GSM, 3G network equipment and CDMA. In this context, the Silk Road Cable Project is also a potentially promising avenue for collaboration between China and Afghanistan, though it has yet to materialize. By investing in the development and expansion of Afghanistan's fiber optic networks, China could help provide considerable benefits to internet users there and in neighboring countries [6].

According to certain analysts, two factors might strengthen the interaction between China and Afghanistan. Firstly, the ability of China to provide the infrastructure development in Afghanistan. Second factor implies traditionally friendly relations between China and Pakistan that might become the basis for an intra-Afghan dialogue through the influence of the Pakistani intelligence services on the Taliban. However, it should be noted that Pakistan is not interested in stabilizing the situation in Afghanistan and strengthening its economic and military power until the territorial disputes along the Durand Line are settled. In this regard, security in the border areas cannot be guaranteed within the project implementation.

In general, the connection between the BRI and Afghanistan and the inflow of foreign investment from China, namely oil and gas exploration projects and railway infrastructure development will foster greater connectivity and enhance security and stability in Afghanistan, while re-establishing itself as a center of economic development in Asia.

The country has already launched projects such as the Sino-Afghan Special Railway Transportation to link Afghanistan to China, via Uzbekistan and Kazakhstan, thereby prioritizing connectivity and embedding it in its foreign policy [7].

A great advantage for Afghanistan would bring the integration into the China-Pakistan Economic Corridor (CPEC), the most monumental project under the Belt and Road Initiative. Since Afghanistan is a landlocked country, Pakistan provides it with the shortest route to marine space. Hence, its inclusion in CPEC would also ensure an easier and more direct access to the Chinese market, in particular, through its link with the Port of Gwadar. New highway and railway plans have been set up from the North to the Port of Gwadar, which serves as a connectivity node and the main access point for energy transportation from the Middle East to Western China [8]. In this regard, China's involvement and prioritization of
CPEC projects could influence and align Afghanistan-Pakistan economic goals and strengthen strategic goals for China's future regional aims.

\section{OBSTACLES FOR AFGHANISTAN TO JOIN THE BRI}

The challenges and obstacles for Afghanistan to join the BRI include the security situation, infrastructure deficit, lack of bilateral and multilateral agreements to facilitate cross-border trade and transit, as well as the political instability.

In particular, security in Afghanistan is vital for the successful implementation of the BRI project in the region. The threat of terrorism and insecurity has potential to obstruct BRI-related projects. Afghanistan has been engulfed by conflict since the 1970s, causing significant damage and destruction to its infrastructure and economy. Afghanistan and Pakistan are in the immediate periphery of China, both sharing a border with the Xinjiang Uygur Autonomous Region facing rebels' threats [9]. Both countries, in general, have been insecure and subject to terrorism for nearly three decades, thus, possessing the potential to destabilize the region.

The insecurity also hampers Afghanistan's connectivity with and integration into the wider region in many ways. For instance, it deters countries from choosing Afghanistan for trade and transit, thus delaying its regional integration. In addition, Afghanistan struggles with an infrastructure deficit and the lack of resources to strengthen the sector. The fragile security situation inhibits foreign investment, including the ones for the infrastructure aimed at the country's integration aspirations, although Afghanistan offers the shortest route for countries in the region to connect with one another [10].

Moreover, Afghanistan's economic challenges are a result of weak governance, poor support of the private sector, complex economic policies, corruption and the inability to uphold the rule of law, all of which discourage investment and connectivity. For instance, Afghanistan's role as a regional transit hub and supplier of energy depends on the government's ability to handle the industry, which is characterized by illegal mining and non-payment of royalties [11]. However, the current government has shown reluctance to take action against criminal networks in the industry, which demonstrates Afghanistan's desire to develop within the regional connectivity.

Having analyzed the range of obstacles for Afghanistan on the way to BRI, many scholars highlight the perspectives of a greater role of China 
as a mediating power, following the US drawdown, between the inter-Afghan parties and also regional affairs in general. Hence, on the political and diplomatic fronts, China is assuming more significant roles, particularly in the peace talks with the Taliban as well as in the mitigation of tensions between Afghanistan and Pakistan [3]. And despite its initial non-interference policy it is creating a more secure environment for the existing and perspective BRI investments [12], which would serve as a crucial step towards improving the security situation in the region, presenting great potential for development, prosperity and long-term growth in Afghanistan.

\section{CONCLUSION}

Afghanistan's geo-strategic location at the crossroads of the region is pertinent, serving as one of the shortest trade routes between Central and South Asia, China and the Middle East, providing easy access to the Arabian sea. Afghanistan could be converted into a vital connectivity hub and demonstrates potential to become a focal point of the BRI. According to Nasir Ahmad Andisha, Deputy Minister for Management and Resources in the Ministry of Foreign Affairs «Regional interconnectivity is the main pillar of our [Afghanistan's] foreign policy to develop and politically stabilize» [13].

For Afghanistan, participation in this project is a good incentive for ensuring security and stability in the country, solving the issue of the population employment and developing interethnic relations by following the common interests of the participating countries. Whereas, economic cooperation and cultural development of the countries of Central Asia and Afghanistan in particular, will contribute to the elimination of terrorism and religious extremism.

Extending of CPEC into Afghanistan may also be helpful in the context of decreasing religious and nationalists' parties rebelling on the AfghanistanPakistan border, which would positively affect the country's transformation to the prosperous one.

Finally, in case the U.S.- led military presence withdraws fully, China might seek to bring Afghanistan closer under its economic and political scope of influence including the Belt and Road Initiative. Whereas, already China has potential to mediate for peace talks between the Taliban, Afghanistan and Pakistan, becoming a major influencer in the region, moving forward the proliferation of its BRI endeavors, which will not only ensure economic benefits for China and the region but also has the potential to contribute greatly to creating a sustainable Afghan economy and enabling it to become a vital hub for trade and transit.

\section{AUTHORS' CONTRIBUTIONS}

Anita Dkhar has provided analysis of documental sources and scientific literature in foreign languages and analysis of China's strategy in Afghanistan.

Mohammad Alem Mohammad Tamim summarized challenges for the modern Afghanistan within the regional affairs.

Saydi Sayed Walid has provided a review of the security factor for Afghanistan's development and perspectives for Afghanistan-Pakistan bilateral relations.

\section{ACKNOWLEDGMENTS}

This paper has been supported by the RUDN University Strategic Academic Leadership Program (recipient: A. Dkhar, analysis of documental sources and scientific literature in foreign languages). The reported study was funded by RFBR, project number 20-314-90004 (recipient: A. Dkhar, analysis of China's strategy in Afghanistan).

\section{REFERENCES}

[1] Joint Statement Between the People's Republic of China and the Islamic Republic of Afghanistan // Consulate General of the People's Republic of China in San Francisco, 20.06.2006. URL:

http://www.chinaconsulatesf.org/eng/xw/t25906 2.htm

[2] F.F. Sharipova, M.A. Dyakonova. The Prospects of the New Silk Road. China and Afghanistan // The 22nd International Scientific Conference China, Chinese Civilization and the World. History, Modernity and Future Prospects. Moscow, Institute of Far East, RAS, 2016. 184 p.

[3] Timon Sharan, Andrew Watkins. Afghanistan Beyond 2021: Inroads for China's Regional Ambitions or Security Spillover? // Afghanistan / Friedrich Ebert-Stiftung (FES), 2021. URL: http://library.fes.de/pdffiles/bueros/kabul/17613.pdf

[4] Chinese envoy criticizes 'prejudice' against BRI at UNSC // China Daily, 16.03.2019. URL: 
https://global.chinadaily.com.cn/a/201903/16/W S5c8cbf01a3106c65c34eefab.html

[5] Afghan media reported that the Afghan-Chinese railroad was put into operation. // Afghanistan.ru, 27.08.2016. URL: http://afghanistan.ru/doc/101441.html

[6] Annie Cowan. Afghanistan Reconnected: Challenges and Opportunities in the Context of China's Belt and Road Initiative // East-West Institute Policy Brief. 2018. Pp.12-13. URL: https://www.eastwest.ngo/sites/default/files/arpchallenges-and-opportunities-in-the-context-ofbri.pdf

[7] D.B. Malysheva. Post-Soviet Central Asia and Afghanistan as a sphere of intersection of interests of large Asian states // RUDN Vestnik.: International relations. 2018. №2. URL: https://cyberleninka.ru/article/n/postsovetskayatsentralnaya-aziya-i-afganistan-kak-sferaperesecheniya-interesov-krupnyh-aziatskihgosudarstv

[8] Deshika Elapata. Does the Belt and Road Initiative have a chance in Afghanistan? // European Institute for Asian Studies, 26.02.2020.

URL: https://www.eias.org/news/does-the-belt-androad-initiative-have-a-chance-in-afghanistan/

[9] V.Y. Belokrenitsky. Armed extremism in Afghanistan, Pakistan and central Asia: a view from Russia // IMEMO RAS, 2017. URL: https://www.imemo.ru/files/File/magazines/puty _miru/2017/01/14Belokrenitskiy.pdf

[10] Mariam Safi, Bismellah Alizada. Afghanistan: Prospects and Challenges to Regional Connectivity // The Diplomat, 19.04.2019. URL: https://thediplomat.com/2019/04/afghanistanprospects-and-challenges-to-regionalconnectivity/

[11] Ahmad Bilal Khalil. Linking Afghanistan to China's Belt and Road. // The Diplomat, 24.04.2017.

URL: https://thediplomat.com/2017/04/linkingafghanistan-to-chinas-belt-and-road/

[12] Abubaker Siddique. New Chinese Grand Strategy to Help Afghanistan. // Gandhara, 29.10.2015.

URL: http://gandhara.rferl.org/a/china-afghanistanone-road-one-belt/27334055.html
[13] Mariam Safi, Bismellah Alizada. Integrating Afghanistan into the Belt and Road Initiative: Review, Analysis and Prospects // Friedrich Ebert-Stiftung, $2018 . \quad$ URL: http://library.fes.de/pdffiles/bueros/kabul/15587.pdf 